\title{
Tiotropis: kas naujo po UPLIFT tyrimo rezultatu paskelbimo
}

\author{
Neringa Vagulienè \\ LSMU MA Pulmonologijos ir imunologijos klinika
}

Reikšmingi žodžiai: lètinė obstrukcinẻ plaučių liga, tiotropis.

Santrauka. Lètinė obstrukcinė plaučių liga (LOPL) - progresuojanti kvejpavimo takų liga, viena dažniausių neigalumo ir mirties priežasčių pasaulyje. Kvėpavimo takų praplètimas, tinkamų bronchus plečiančių vaistų parinkimas - tai LOPL gydymo pagrindas. Tiotropis - vienintelis ilgo veikimo anticholinerginis vaistas, patvirtintas LOPL gydyti.

\section{IVADAS}

Lètinè obstrukcinė plaučių liga (LOPL) yra patologinė būklè, kuriai būdinga nevisiškai išnykstanti, progresuojanti bronchų obstrukcija, sukeliama neịprasto plaučių atsako uždegimu i ¡̇kvepiamąsias kenksmingas daleles ar dujas. Tai viena iš dažniausių mirties ir neigalumo priežasčių pasaulyje [1]. Šiai ligai būdingi plaučių emfizemos ir lètinio bronchito patomorfologiniai pokyčiai. Bronchus plečiančių vaistų vartojimas - LOPL gydymo pagrindas.

Tiotropis yra anticholinerginis vaistas, kuris veikia per pagrindinị grịžtamąji LOPL mechanizmą - cholinerginị bronchų spazmą. Tiotropis sukelia ilgalaiki bronchus plečiantị poveikị ir sumažina hiperinfliaciją (oro spąstus). Jis yra efektyvus ir saugus vaistas, kuri paprasta vartoti, pakanka tik vienos inhaliacijos per parą. Respimat - tai naujos technologijos inhaliatorius, kuris pasižymi unikalia ir sudètinga paskirstymo sistema. Pro Respimat išpurškiamas lètai judantis drėgnas vaisto srautas Soft Mist užtikrina, kad tiotropis geriau patenka i plaučius, lyginant su slèginiu dozuotu inhaliatoriumi (pMDI), mažiau vaisto nusèda burnoje ir gerkleje. Šiame straipsnyje apžvelgiami tyrimai bei lyginamas Respimat Soft Mist technologijos ir sausu milteliu inhaliatorių (HandiHaler) veiksmingumas.

\section{TIOTROPIS HANDIHALER}

UPLIFT (angl. Understanding Potential Long-term Impacts on Function with Tiotropium) tyrimo duomenys pirmą kartą paskelbti 2008 metais. Tai itin didelès apimties tyrimas: jame dalyvavo 5993 LOPL sergantys ligoniai (GOLD angl. Global Initiative for Chronic Obstructive Lung Disease) iš 490 tyrimo centru 37 pasaulio šalyse, i̇skaitant Lietuvą. Šiame tyrime, kuris truko ketverius metus, lygintas tiotropio po $18 \mu \mathrm{g}$ vieną kartą per parą ir placebo poveikis LOPL. Nustatyta, kad tiotropis suletina plaučių funkcijos blogèjimo greitị ir ligos paūmèjimų ri- ziką [2]. Atlikus tyrimo pogrupio analizę, išsiaiškinta, kad pradejjus nuolat gydyti tiotropiu vidutinio sunkumo LOPL sergančius pacientus, iki tol negydytus kitais vaistais (inhaliuojamaisiais gliukokortikoidais, ilgai veikiančiais beta agonistais, teofilinu ar anticholinerginiais vaistais), plaučiu funkcijos blogèjimo greitis buvo mažesnis, pagerejjo klinikinè būklè [3]. Kadangi nustatyta, jog tiotropio grupejje plaučių funkcija ir su sveikata susijusi gyvenimo kokybè buvo geresnè nei kontrolinėje, gydymą rekomenduojama pradèti esant vidutinio sunkumo LOPL. Kiti klinikiniai tyrimai patvirtino šiuos rezultatus. R. W. Negro su bendradarbiais atliko retrospektyvųji tyrimą: išanalizavo duomenis lengva, vidutinio sunkumo ir sunkia LOPL sergančių pacientu, gydytu $18 \mu \mathrm{g}$ tiotropiu vieną kartą per parą, ir pastebėjo, kad tiotropis veiksmingesnis, kai bronchų obstrukcija mažesnè. Buvo patvirtinta, kad anticholinerginiu vaistu tiotropiu naudinga gydyti ankstyvos stadijos LOPL sergančius pacientus [4]. Tyrimais įrodyta, kad gydymas ilgo veikimo anticholinerginiu vaistu tiotropiu suteikia papildomos naudos sergant vidutinio sunkumo LOPL, taigi rekomenduojama gydymą pradèti kuo anksčiau.

\section{TIOTROPIS RESPIMAT}

Klinikiniu tyrimu ar analizių, skirtu palyginti tiotropio Respimat veiksmingumą su tiotropio HandiHaler, nèra daug. T. Voshaar ir bendradarbiai [5] lygino 5 bei 10 $\mu \mathrm{g}$ tioptropio Respimat poveiki su ipratropio ir placebo dviejuose identiškose 12 savaičių trukmès tyrimuose. Šiu tyrimų pagrindinis tikslas - įvertinti $\mathrm{FEV}_{1}$ pokyti gydymo pabaigoje. Abiejuose tiotropio Respimat grupèse (5 ir $10 \mu \mathrm{g}$ ) ne tik $\mathrm{FEV}_{1}$, bet ir kiti plaučiu funkcijos rodikliai buvo geresni nei ipratropio bei placebo grupèse. Kitame tyrime [6], kuriame lygintas 5 ir $10 \mu \mathrm{g}$ tiotropio Respimat veiksmingumas su placebo, siekta įvertinti $\mathrm{FEV}_{1}$ pokyti, gyvenimo kokybę naudojant šv. Jurgio ligoninès klausimyną (angl. St. Georges Respiratory Questionnaire, 
$S G R Q)$, trumpalaikio dusulio indekso skalę 48 savaites bei LOPL paūmejjimus per metus. Abiejuose tiotropio Respimat grupèse $(5$ ir $10 \mu \mathrm{g}$ ) nustatytas reikšmingas efektas lyginant su placebo grupe, tačiau pacientams, gydytiems $10 \mu \mathrm{g}$ tiotropio, dažniau pasireiškè anticholinerginis šalutinis poveikis.

Dar viename didelès apimties atsitiktinių imčių placebu kontroliuojamame dvigubai aklame tyrime dalyvavo 3991 LOPL sergantis pacientas $\left(\mathrm{FEV}_{1}<60\right.$ proc.) [7]. Jie 48 sav. gydyti tiotropio Respimat $5 \mu \mathrm{g}$ vieną kartą per parą ir galejo vartoti kitų inhaliuojamųjų vaistų, išskyrus anticholinerginius. Pagrindiniai tyrimo tikslai buvo pasiekti: statistiškai reikšmingai pagerejjo $\mathrm{FEV}_{1}$ bei po gydymo pailgèjo laikas be LOPL paūmèjimo.

J. A. van Noord su bendradarbiais [8] palygino tiotropio, vartojamo pro Respimat ir HandiHaler, efektyvumą bei saugumą. Jie išanalizavo du panašius tyrimus ir palygino tiotropio Respimat 5 ir $10 \mu \mathrm{g}$ grupes su tiotropio 18 $\mu \mathrm{g}$ HandiHaler bei placebo grupemis. Pagrindinis tyrimo tikslas - palyginti FEV 1 pokyčius. Visose gydymo tiotropiu grupèse $F E V_{1}$ pagerèjo reikšmingai labiau nei placebo. 5 ir $10 \mu \mathrm{g}$ tiotropio Respimat grupèse $\mathrm{FEV}_{1}$ pokyčiai nesiskyré, bet buvo statistiškai reikšmingai geresni nei tiotropio HandiHaler grupèje. II fazès klinikinio tyrimo, kuriame lygintas tiotropio Respimat $5 \mu \mathrm{g}$ ir HandiHaler poveikis, rezultatai buvo panašūs, nors tyrimas mažesnès apimties ir trumpesnis [9].

\section{TIOTROPIS IR KITI INHALIUOJAMIEJI VAISTAI}

Tiotropis yra efektyvus ir vertingas inhaliuojamasis bronchodilatatorius, vartojamas palaikomajam gydymui tiek vienas, tiek kartu su ilgai veikiančiais beta agonistais ar inhaliuojamaisiais gliukokortikoidais. Derinant tiotropi su inhaliuojamaisiais beta agonistais ir gliukokortikoidais, LOPL sergantiems pacientams suretejja paūmejjimai ir sumažèja hospitalizavimo dèl jų dažnumas. Be to, kai kuriais klinikiniais tyrimais buvo palygintas LOPL pacientų gydymo efektyvumas trimis vaistais, iskaitant tiotropiu, su gydymo deriniu be tiotropio [10]. Panašus funkcijos pagerejjimas nustatytas abiejuose tiriamųjų grupèse [11], kai $18 \mu \mathrm{g}$ tiotropio vartota kartu su salmeteroliu/flutikazonu $50 / 250 \mu \mathrm{g}$, tuo tarpu kiti tyrimai rodo, kad gydant deriniais su tiotropiu LOPL paūmėjimų rizika ir skaičius sumažejo labiau nei gydant salmeteroliu ir trumpo veikimo anticholinerginiu vaistu (ipratropiu). Pastebèta, kad tiotropis skatina CD4(+)T/CD8(+) Treg ląstelių ir slopina CD25(+)T ląstelių aktyvumą, kurios yra svarbios LOPL patogenezėje [12].

\section{IŠVADA}

Hiperinfliacija, ribotas iškvepiamo oro srautas, bronchų obstrukcija yra pagrindiniai sergančių LOPL klinikinių tyrimų tikslai. Atsižvelgiant $\mathfrak{i}$ tai, ilgo veikimo anticholinerginiai bronchus plečiantys vaistai turi būti pirmaeiliai gydant obstrukcines plaučių ligas. Naujas $5 \mu \mathrm{g}$ tiotropio Respimat inhaliatorius užtikrina, kad tiotropis i plaučius patenka geriau nei naudojant HandiHaler (slègini dozuotą inhaliatorių), todèl labiau pagerina plaučių funkcijos rodiklius, sumažina paūmèjimų skaičių ir pagerina gyvenimo kokybę.

\section{TIOTROPIUM: WHAT CAME AFTER THE UPLIFT STUDY}

\section{NERINGA VAGULIENE \\ DEPARTMENT OF PULMONOLOGY AND IMMUNOLOGY LITHUANIAN UNIVERSITY OF HEALTH SCIENCES}

Keywords: chronic obstructive pulmonary disease, tiotropium.

Summary. Chrronic obstructive pulmonary disease (COPD) is a progressive that restricts patients livesover time and is a major cause of death and disability throughout the world. Bronchodilatators represent the maintenance terapeutic choise of COPD treatment. Tiotropium it an long-acting anticholinergic drug that is proved to be safe, effecient and simple to handle.

\section{LITERATŪRA}

1. Global Initiative for Chronic Obstructive Lung Disease: Global strategy for the diagnosis, management, and prevention of chronic obstructive pulmonary disease. http://www.goldcopd.org/uploads/users/files/GOLD_Report_2011 Feb21.pdf

2. Tashkin DP, Celli B, Senn S et al. A 4-year trial of tiotropium in chronic obstructive pulmonary disease. N Engl J Med 2008; 359: 1543-54.

3. Decramer $M$, celli $B$, Kesten $S$ et al. Effect of tiotropium on outcomes in patients with moderate chronic obstructive pulmonary disease (UPLIFT): a prespecified subgroup analysis of a randomised controlled trial. Lancet 2009; 374: 1171-8.

4. Dal Negro RW, Bonadiman L, Micheletto $C$ et al. Changes of clinical outcomes and health care resources in moderate and in Severe COPD treated uniquely with tiotropium $18 \mathrm{mcg}$ od for twenty-four months. Pulm Pharmacol Ther 2011; 24: 373-6.

5. Voshaar T, Lapidus R, Maleki-Yazdi R, et al. A randomized study of tiotropium Respimat ${ }^{\oplus}$ Soft Mist inhaler vs ipratropium pMDI in COPD. Respir Med 2008; 102: 32-41.

6. Bateman E, Singh D, Smith D et al. Efficasy and safety of tiotropium Respimat ${ }^{\circledR}$ SMI in COPD two 1-year randomized studies. Int J Chron Obstruct Pulmon Dis 2010; 5: 197-208.

7. Bateman ED, Tashkin D, Siafakas $\mathrm{N}$ et al. $\mathrm{A}$ one-year trial of tiotropium Respimat ${ }^{\oplus}$ plus usual therapy in COPD patients. Respir Med 2010;104:1460-72.

8. Van Noord JA, Cornelissen PJ, Aumann JL et al. The efficasy of tiotropium administered via respimat soft mist inhaler or HandiHaler in COPD patients. Respir Med 2009; 103: 22-9.

9. Ichinose M, Fujimoto T, Fukuchi Y. Tiotropium 5 microg via Respimat and 18 microg via HandiHaler: efficacy and safety in Japanese COPD patients. Resp Med 2010; 104: 228-36.

10. Karner C, Cates CJ. Combination inhaled steroid and long-acting beta(2)agonist in addition to tiotropium or combination alone for chronic obstructive pulmonary disease. Cochrane Database Syst Rev 2011; 16: CD008532.

11. Bateman ED, van Dyk M, Sagriotis A. Comparable spirometric efficacy of tiotropium compared with salmeterol plus fluticasone in patients with COPD: a pilot study. Pulm Pharmacol Ther 2008; 21: 20-5.

12. Zhang J, Deng $L$, Xiong $X$ et al. Effect of tiotropium bromide on expression of $\mathrm{CD}(8)(+) \mathrm{CD} 25(+)$ FoxP $(3)(+)$ regulatory T cells in patients with stable chronic obstructive pulmonary disease. J Huazhong Univ Sci Technolog Med Sci 2011; 31: 463-8. 